\title{
How to Attract Talented Expatriates: The Key Role of Sustainable HRM
}

\author{
Gahye Hong ${ }^{1}\left(\mathbb{D}\right.$ and Eunmi Kim ${ }^{2, *(D)}$ \\ 1 Business Administration, Korea University, Anam-ro 145, Seoul 02841, Korea; gahyehong@korea.ac.kr \\ 2 Graduate School of International Studies, Pusan National University, Busandaehak-ro 63, Geumjeong-gu, \\ Busan 46241, Korea \\ * Correspondence: eunmikim@pusan.ac.kr; Tel.: +82-51-510-2541
}

Received: 30 August 2019; Accepted: 26 September 2019; Published: 28 September 2019

check for updates

\begin{abstract}
Retaining talented expatriates is important for multinational enterprises (MNEs) to maintain knowledge sustainability between their headquarters (HQ) and subsidiaries. However, depending on the host country image of a subsidiary, the attractiveness of the subsidiary may make it challenging to recruit prospective expatriates. Based on the sustainable human resource management (HRM) perspective, this study examines the direct effect of the host country image of a subsidiary and the moderating effect of family support policies on a subsidiary's attractiveness, by comparing subsidiaries in the US and Vietnam. The results are based on data from 434 Korean potential expatriate applicants and show that the host country image of a subsidiary has a direct effect on the subsidiary's attractiveness. Specifically, expatriate applicants are less attracted to a Vietnam-based subsidiary than to a US-based one. Further, the positive moderating effect of family support policies on subsidiary attractiveness is more relevant for the Vietnam-based subsidiary. This result suggests that family support policies can be a key strategy for overcoming the less preferred host country images of subsidiaries in emerging markets, thus improving subsidiary sustainability in the long term. The implications of these findings are provided in the context of sustainable HRM and the existing expatriate literature.
\end{abstract}

Keywords: sustainable human resource management; expatriate; organizational attractiveness; country image; family support policy

\section{Introduction}

Retaining talented expatriates is a key consideration for MNEs to sustainably survive in today's oversaturated worldwide markets, as MNEs must transfer core knowledge from their HQ across geographically dispersed subsidiaries. Expatriates refer to employees who deploy knowledge from the $\mathrm{HQ}$, including technological skills and organizational practices and cultures, across other geographically dispersed subsidiaries for a certain period of time [1]. Thus, talented expatriates play a key role in maintaining knowledge sustainability among an MNE's subsidiaries and, consequently, affect sustainable subsidiary performance by transferring managerial and technical knowledge from the HQ [2]. In the long term, recruiting and selecting prospective expatriates who can successfully accomplish foreign assignments in global subsidiaries can allow MNEs to achieve a sustainable competitive advantage. Despite the important roles of expatriates, MNEs often face greater challenges in recruiting prospective expatriate candidates to send to geographically dispersed subsidiaries as international mobility is not an easy decision for every employee [3,4]. The situation is more difficult when subsidiaries are located in emerging economies, as these are considered riskier for expatriates to work and live in yet carry strategic potential for MNEs [5]. Thus, it is worth investigating the challenges that may affect an expatriate's destination choice and how such challenges can be strategically overcome. 
The image of host countries appears to largely affect the attractiveness of expatriate destinations because expatriates, not only work, but also live in these destinations [6]. According to signaling theory [7], potential expatriate applicants have incomplete information about subsidiary locations. Thus, the images or stereotypes of an expatriate destination can be relevant for evaluating its working and living conditions. As a particular country's image is created in terms of its economic, technological, and political development [8], it is highly likely that prospective expatriate applicants are less attracted to expatriate destinations in emerging countries, than those in advanced economies [9]. A recent extensive survey of expatriates has shown that emerging countries, such as China, Brazil, and India, are selected as the most challenging assignment locations for expatriates [10]. However, emerging markets have become strategically more important for MNEs to gain sustainable competitive advantages, as they have positive business outlooks and fast growth rates [5]. Nevertheless, few studies identify the effect of images of emerging markets as expatriate destinations on the attractiveness of subsidiaries for international assignments. Thus, the first purpose of this study is to examine the influence of the subsidiary country's image on the attractiveness of an expatriate destination by comparing the abilities of a developing country (Vietnam) and a developed country (the US) to attract potential expatriates.

According to a recent survey on expatriation, over $70 \%$ of expatriates are accompanied by family members, such as partners and children, to their expatriate destinations. Moreover, the results of this survey also show that family maladjustment is a major cause of expatriate failure because expatriates' families' lives commonly spill over to their work lives $[5,10]$. Thus, it is plausible that the success of a foreign assignment largely depends on the family adjustment in unfamiliar expatriate destination [11-13].

Sustainable human resource management (HRM) has gained considerable attention in the literature on human resources (HR) [14-16]. It argues that HR practices, concerning positive human outcomes, including employees' work-life balance, result in sustainable organizations and long-term survival [17]. Prior research related to work-life balance finds that adopting family support programs is positively related to employees' job satisfaction and organizational commitment [18-20]. That is, organizations' family support policies help employees balance their work and their lives. By expanding the sustainable HRM perspectives to the literature on expatriates, this study also aims to suggest that family support policies in foreign subsidiaries can potentially moderate the relationship between a foreign subsidiary's country image and its organizational attractiveness to expatriates. Particularly, this effect should be more dominant when nationally dispersed subsidiaries are in emerging economies with unfavorable country images rather than in developed ones.

We examined the underlying issues by investigating the attractiveness of Korean subsidiaries in Vietnam and the US among Korean potential expatriate applicants. From 2008 to 2017, Korea's largest outward foreign direct investment (OFDI) was the US (US $\$ 77.3$ billion, $24.6 \%$ of investment). Moreover, Korea is the leading recipient of Vietnam's OFDI in Asia, as Vietnam was ranked the third-largest destination for OFDI (about US \$5 billion) in 2017 [21]. Consequently, both countries are an important and popular FDI destination for Korean MNEs. Accordingly, Korean expatriates in those two countries are continuously increasing. Furthermore, Koreans are mindful about family, as it is heavily influenced by Confucianism, which values a loyal relationship between family members [22]. Consequently, potential Korean expatriates will be an appropriate sample to investigate the image of the host countries, specifically the US and Vietnam, and the effect of family support programs in these host countries.

This study contributes to the sustainable HRM and expatriate literature in several ways. First, it identifies a host country image as one of the major challenges in attracting talented expatriate applicants to subsidiaries in emerging countries, by examining US-based and Vietnam-based subsidiaries, in order to attract Korean expatriate applicants. Thus, this study contributes to the understanding of the challenges of attracting potential expatriate applicants to subsidiaries in emerging countries. Second, it applies signaling theory to explain the attractiveness of expatriate subsidiaries. Few studies adopt these two theories in this context, and, thus, applying both theories in the context of expatriates can help clarify how to attract prospective expatriate applicants to international assignment locations. Third, based on the perspective of sustainable HRM, we introduced family support policies as a strategy to 
overcome the effect of a less favorable host country image on the organizational attractiveness of a foreign subsidiary. Given that it is difficult to change the image of a host country and its effects on the organizational attractiveness of a given subsidiary, implementing family support policies for expatriate candidates as a strategy to overcome these challenges can enrich and broaden the scope of sustainable HR practices. Moreover, such a strategy can help nationally dispersed subsidiaries become sustainable in the long run by transferring knowledge from their HQ through talented expatriates.

The remainder of this paper is structured as follow. First, the theoretical framework and relevant literature are reviewed. Then, the data are analyzed, and the results are explained and discussed. Finally, the conclusions, implications, and limitations of this study are provided.

\section{Literature Review and Hypothesis Development}

\subsection{Sustainable HRM and the Attractiveness of a Subsidiary}

For more than a decade, sustainable HRM has gained considerable attention as a response to rapid changes in employee relations, labor markets, and societal levels $[15,23]$. Sustainable HRM has no consensus definition, but it has been used to refer to human, social, and environmental outcomes that largely contribute to the long-term survival of an organization [15]. Unlike the existing HRM literature, sustainable HRM suggests a new perspective on people management by focusing on sustainable HR development, regeneration, and renewal [24]. In a recent study, Wehling et al. [25] suggests five core characteristics of sustainable HRM practice: Rationale (motivation, trigger, and benefits), conceptual framework (model and terminology), direction (functional responsibility and hierarchical accountability), transfer (implementation mechanism and knowledge transfer), and evaluation (awards, benchmarking, metrics, and content of reports). In particular, the ability to create and transfer knowledge from a parent company to foreign subsidiaries, and vice versa, might be a crucial source for important competitive advantage of MNEs [26].

In fierce international markets, MNEs might meet diverse challenges to compete against local and international competitors. To overcome the liability of foreignness in foreign markets and achieve sustainability across the organization, expatriates have significant roles in transferring managerial and technological knowledge from HQ to subsidiaries [27]. Also, they fill a human capital need in nationally dispersed subsidiaries. As expatriates play a key role in transferring HQ knowledge, recruiting superior expatriates is crucial in enhancing subsidiary performance and achieving the entire MNEs' sustainability in the long run [2]. Even though expatriates have this critical role in achieving sustainable performance for the MNE, many organizations generally struggle to recruit and select superior expatiates. Further, the existing expatriate literature have largely neglected the expatriate recruitment stage and how potential applicants are attracted to foreign assignment destination.

The recruitment literature regards organizational attractiveness as crucial for attracting prospective applicants. Scholars introduced the concept of organizational attractiveness and have examined it both, empirically and theoretically, over the last two decades. Organizational attractiveness is defined as the applicants' willingness to pursue jobs and accept job offers in an organization (e.g., [28,29]). Turban et al. [30] argue that organizational attractiveness is crucial because any loss of prospective applicants in the first phase of recruitment can reduce the utility of the selection system. Thus, investigating why potential applicants are attracted to organizations is critical because organizational attractiveness is significantly related to job pursuit intentions and job choice behaviors [31]. Based on the above logic, we modified the original version of the organizational attractiveness to the attractiveness of a subsidiary, as an expatriate destination, because organizational attractiveness is among the strongest predictors of employees' job pursuit intentions and actual job choice behavior. Moreover, prior studies found that candidates who are more willing to expatriate are more likely to accept international assignments and adjust well to an unfamiliar host country than less willing candidates [12,32]. Likewise, expatriate candidates, who are attracted to certain subsidiaries, have a higher chance of accepting and completing international assignments successfully. 


\subsection{Host Country Images of Subsidiaries}

A country image refers to the stereotypes or bias that an individual or organization may hold towards a certain country in terms of the economic, technological, and political development dimensions $[9,33]$. This has been examined as one of the major factors affecting potential applicants' job choice intention and organizational attractiveness in the recruitment literature [9,34,35]. Signaling theory has been adopted to explain how potential job seekers can be influenced by signals about a characteristic of companies revealed during the recruitment process [7,36]. Specifically, potential job seekers often cannot obtain complete information regarding organizations in the early stages of their job choice decisions [7]. Under such conditions, symbolic images, including the country image, company reputation, and organizational characteristics, can largely signal the unknown organizational characteristics, thus affecting the attractiveness of an organization [37-39]. That is, a country image, which consists of economic, technological, and political images can, in part, signal or create unknown characteristics of organization, thus affecting the organizational attractiveness. Applying this logic to the expatriate attraction process, we argue that potential expatriate applicants also do not have complete information about foreign assignment destinations in terms of working conditions and living standards, including children's education systems, social infrastructures, and safety. When there is insufficient information about the assigned destinations, the expatriate's images or stereotypes of the country can create and signal unknown subsidiary characteristics, including working and living environments that influence the subsidiary's attractiveness [6]. Specifically, subsidiaries located in developed countries are generally evaluated more positively than those in emerging countries. That is, potential expatriate applicants may perceive expatriate destinations in developed countries as having better working conditions and social infrastructures, higher living standards, and more advanced career opportunities, simply because they are located in advanced economies. However, they may perceive host locations in emerging countries as having worse working conditions and social infrastructures, lower living standards, and fewer career opportunities, owing to these countries' less favorable host country images. Consequently, potential expatriate candidates will be more attracted to host locations in economically, technologically, and politically developed countries, compared to those in emerging countries. Many empirical findings support our argument. For example, Kim and Froese [4] found that a host country's level of economic development was positively related to employees' willingness to expatriate, based on a sample of 151 married Korean employees. De Eccher and Duarte [6] found that the socio-political (safety and political issues) and symbolic (attraction to host culture) images of host countries were significantly associated with expatriates' relocation decisions. In line with the above argument, we expect Korean expatriate candidates to be more attracted to the US as an expatriate destination than to Vietnam, because they may perceive the Vietnam-based subsidiary as having poor working conditions and quality of life simply because it is located in an emerging economy. This idea leads to Hypothesis 1:

Hypothesis (H1): Korean expatriate applicants are less attracted to a Vietnam-based subsidiary as an expatriation destination, compared to a US-based subsidiary.

\subsection{Family Support Policies}

Given the surge of dual-earner couples, women, and single parents in today's workforce [40], many MNEs have started to offer policies to help their employees manage work and family [41]. Family-friendly policies are HR policies that organizations implement in response to the family-oriented needs of their workers, and may include policies regarding child and elder care, flexible scheduling, and family leave [42]. Childcare support may be provided in the form of on-site centers, referral programs, or financial assistance. Bourdieu [43] points out that family policies are state activities that aim to favor a certain kind of family organization and to strengthen those who can conform to this organization. Over the last few decades, scholars studying work-family issues have argued that the prevention of work-family conflicts is becoming an increasingly urgent problem for companies. Several 
empirical studies found that, when organizations adopt family support programs to retain talented employees, they observe more positive work-related outcomes, including organizational commitment and job satisfaction, and fewer negative outcomes, such as work-family conflicts [18-20,44].

Family issues are also a major research interest in the expatriate literature [45], as more than half of expatriates are accompanied by their families in international assignments [11]. Ample evidence suggests that a major factor influencing expatriate ineffectiveness, during international assignments, is the inability of an employee's spouse and children to adapt to the host country [11,46]. Furthermore, Tharenou [12] found that employees' willingness to expatriate was reduced when their families, including their partners and children, disapproved of their expatriating.

Extending the above findings, we argue that family concerns are indeed important when considering international assignments. Thus, we suggest that family support programs in subsidiaries can be a strategy for attracting talented expatriate candidates. As mentioned above, signaling theory suggests that, because potential expatriate applicants may have limited information about their assignment locations, organizational attributes can signal the overall working environment [7]. Thus, family support policies of assignment locations may signal the overall work and non-work aspects of assignment locations. Taking an international assignment is not an easy decision for employees and their accompanying families because they have to deal with unfamiliar working and living conditions, including different cultural norms, laws, languages, health care, and safety [47]. Thus, when considering expatriation, potential applicants will be anxious and uncertain about whether they, and their families, can adapt to the expatriate destination. Under such conditions, family support programs of assignment destinations can signal that the overall working and living conditions in the expatriate destination are reliable. Specifically, expatriate applicants can assume that their company will try its best to help them and their families set up new lives, through family support programs, thus increasing the attractiveness of the assignment location. However, this effect should be more dominant for expatriate destinations in emerging countries. As mentioned in the above discussion, subsidiaries, located in emerging countries, may be perceived as less attractive than those located in developed countries owing to their less favorable country images. That is, expatriate candidates may presume that subsidiaries in emerging countries, such as Vietnam, are not good places to work and live. In particular, this biased perception regarding the image of emerging countries is heightened when employees consider their families accompanying them. Under such conditions, implementing family support policies in assignment subsidiaries in emerging countries can ease biased images of the host location, thus increasing the attractiveness of the assignment location. In contrast, expatriate destinations in developed countries, such as the US, are already perceived as good places to work, owing to more favorable country images, and, thus, the effect of subsidiaries' family support programs on organizational attractiveness should be significant for subsidiaries in emerging countries. Based on this discussion, we put forth Hypothesis 2:

Hypothesis (H2): The positive moderating effect of family support policies on the relationship between host country image and the attractiveness of a subsidiary is stronger when the assignment location is in Vietnam than when it is in the US.

\section{Methods}

\subsection{Research Design}

This study involved 2 (host-locations: Vietnam versus the US) $\times 2$ (family support policies: No policy versus a good policy) between-subjects experimental design to examine the impact of expatriation destinations and family support policies on the attractiveness of foreign subsidiaries. Four hypothetical corporation scenarios were created based on the host locations of foreign subsidiaries and the family support policies in the expatriation destinations. The instructions for each scenario provided basic information regarding the locations where respondents would be sent as expatriates to the US or Vietnam in the near future after a short training in Korea. For a better understanding of 
the host locations and family support policies, each scenario included repeated information on the expatriation destinations and family support policies for adjusting to the new surroundings, such as extra support for families, tuition fees for children, and on-site childcare facilities.

\subsection{Participants}

To explore the impacts of host locations and family support policies on the attractiveness of expatriate subsidiaries, Korean full-time workers with families were approached to participate in the study. In total, 434 full-time workers took part in the study considering expatriation destinations (Vietnam versus the US) and family support policies (no policy versus a good policy). The sample comprises a slightly proportionate males $(n=226 ; 52.1 \%)$ than females $(n=226 ; 47.9 \%)$. The age range was from 24 to 64 years, and their average age was 40.89 years $(S D=8.03)$. In particular, as shown in Table 1, the sample consists a high proportion of individuals in the category between 36 and 45 years. In addition, participants who have bachelor's degrees were 259 (59.7\%), and 291 participants $(67.05 \%)$ did not have any living experience abroad. Moreover, 222 participants (51.2\%) have been working at the organization for over 10 years.

Table 1. Sample profile.

\begin{tabular}{cccccc}
\hline Age (Years) & $\boldsymbol{n}$ & $\mathbf{( \% )}$ & Education & $\boldsymbol{n}$ & $\mathbf{( \% )}$ \\
\hline $24-30$ & 38 & $(8.76)$ & High school & 54 & $(12.44)$ \\
$31-35$ & 86 & $(19.82)$ & Associate degree & 75 & $(17.28)$ \\
$36-40$ & 95 & $(21.89)$ & Bachelor's degree & 259 & $(59.68)$ \\
$41-45$ & 101 & $(23.27)$ & Master's degree & 40 & $(9.22)$ \\
$46-50$ & 53 & $(12.21)$ & Ph.D. degree & 6 & $(1.38)$ \\
Above 50 & 61 & $(14.05)$ & & & \\
\hline International Experience (Years) & $\boldsymbol{n}$ & $\mathbf{( \% )}$ & Working Experience (Years) & $\boldsymbol{n}$ & $\mathbf{( \% )}$ \\
\hline None & 291 & $(67.05)$ & Below 1 & 28 & $(6.45)$ \\
$0-1$ & 83 & $(19.12)$ & $1-4$ & 65 & $(14.98)$ \\
$1-4$ & 46 & $(10.60)$ & $5-10$ & 119 & $(27.42)$ \\
$5-10$ & 11 & $(2.54)$ & Above 10 & 222 & $(51.15)$ \\
Above 10 & 3 & $(0.69)$ & & & \\
\hline
\end{tabular}

\subsection{Procedures}

Participants responded through a Qualtrics online survey that randomly showed one of four between-subjects conditions. Two scenarios did not include information on family support policies and only conveyed information on the expatriation destination (Vietnam or the US). Whereas, the other two scenarios included corporate information on good family support policies and the host location. Each participant was given a packet containing instructions, an individual information survey, and a scenario card. Respondents were asked to imagine themselves as expatriate candidates in organizations with the characteristics depicted in the scenarios. After reading each scenario precisely, the participants were asked to answer a series of questions on the attractiveness of the subsidiaries from the perspective of an expatriate candidate.

\subsection{The Attractiveness of a Subsidiary as a Dependent Variable}

This study adapted the Turban [48] measure of organizational attractiveness in an expatriation context, as follows: "I would exert a great deal of effort to work for this subsidiary," "I would like to work for this subsidiary," "I would choose this subsidiary as a top choice for an expatriate," and "I would eventually accept this expatriate assignment." A six-point Likert-type scale, ranging from 1 (definitely disagree) to 6 (definitely agree), was used to assess these statements. Overall attractiveness of a foreign subsidiary as an expatriate destination was computed as the mean of the scores for the four items $(\alpha=0.929)$. 


\section{Results}

To test the predictions of the hypotheses, we conducted a two-way ANOVA test that included the main effects of host locations and family support policies on the attractiveness of expatriate subsidiaries, as well as the effect of the interaction between host locations and family support policies. Table 2 shows that host locations had a significant direct effect on the attractiveness of foreign subsidiaries $\left(F(1,430)=15.597, p<0.001, \eta_{p}^{2}=0.035\right)$. This result shows that Korean workers prefer the US $(\mathrm{M}=3.26, \mathrm{SD}=0.941)$ to Vietnam as a host location in terms of the attractiveness of an expatriate subsidiary $(\mathrm{M}=2.88, \mathrm{SD}=0.913)$. Thus, Hypothesis 1 was supported.

Table 2. Two-way ANOVA for the attractiveness of foreign subsidiaries.

\begin{tabular}{cccccc}
\hline & $d f$ & MS & F-Value & $p$-Value & Partial $\eta^{2}$ \\
\hline Host-locations & 1 & 14.612 & 15.597 & 0.000 & 0.035 \\
Family support policies & 1 & 42.349 & 45.205 & 0.000 & 0.095 \\
Host-locations $\times$ Family support policies & 1 & 17.430 & 18.605 & 0.000 & 0.041 \\
Error & 430 & & 0.937 & & \\
\hline
\end{tabular}

As shown in Table 2, the effect of the interaction between host locations and family support policies on the attractiveness of an expatriate subsidiary was significant $(F(1,430)=18.605, p<0.001$, $\eta_{p}^{2}=0.041$ ). Additionally, as shown in Table 3, planned contrasts revealed that Korean workers are more attracted to Vietnam when good family support policies were in place $(\mathrm{M}=4.48, \mathrm{SD}=0.939)$, than when no such policies were in place $(\mathrm{M}=3.45, \mathrm{SD}=1.012)(F(1,430)=52.147, p<0.001)$. However, Korean workers' intentions did not differ significantly across good family support policies $(\mathrm{M}=4.44$, $\mathrm{SD}=0.893)$ and no family support policies $(\mathrm{M}=4.23, \mathrm{SD}=1.027)$ when the USA is the expatriate location $(F(1,430)=2.705, p>0.10)$. These results supported Hypothesis 2 . That is, the positive moderating effect of family support policies on the relationship between the host location and the attractiveness of a foreign subsidiary to Korean workers is stronger when Vietnam rather than the US is the assignment location.

Table 3. Planned contrasts for the attractiveness of foreign subsidiaries.

\begin{tabular}{llcccc}
\hline & & $d f$ & SS & F-Value & $p$-Value \\
\hline No vs. Good family support policies & Vietnam & 1 & 54.754 & 52.417 & 0.000 \\
& The US & 1 & 2.840 & 2.705 & 0.101 \\
\hline
\end{tabular}

Figure 1 illustrates the simple effect of family support policies. The difference between no family support policies and good family support policies was significant only for participants considering the Vietnam scenario, and participants in this condition tended to be more attracted to a subsidiary with good family support policies, than to a subsidiary with no family support policies. However, for participants considering the US as an expatriate location, the mean attractiveness with good family support policies did not significantly differ from that with no family support policies. Based on these results, family support polices may be a key factor influencing the attractiveness of expatriate subsidiaries, particularly when the assignment location is a less favorable country. 

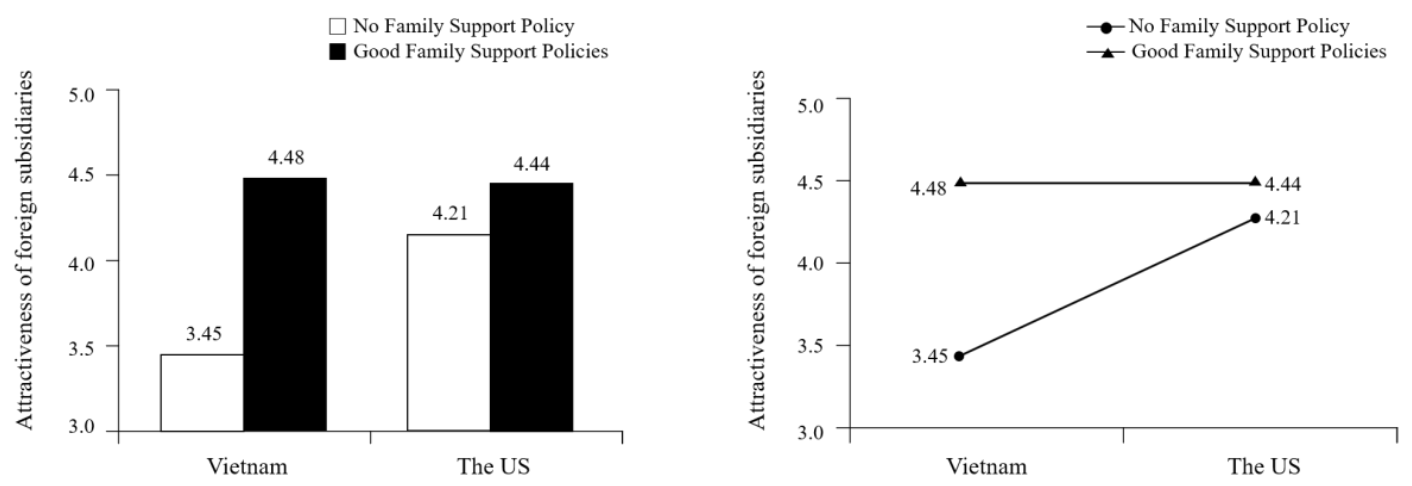

Figure 1. The effects of host-locations and family policies on the attractiveness of foreign subsidiaries.

\section{Discussion}

Overall, the findings support our theoretical framework and show that host country images of subsidiaries, in emerging and developed markets, differently influence the attractiveness of expatriate destinations to potential expatriate applicants. Moreover, the positive moderating effect of family support policies on the relationship between the host country's image and organizational attractiveness to potential expatriate applicants, was stronger for an emerging market subsidiary than for a developed market subsidiary. More specifically, we found that Korean potential expatriate applicants were less attracted to a Vietnam-based subsidiary as an expatriate destination, compared to a US-based one owing to Vietnam's less preferred host country. This result validates our argument that host country image can be a greater obstacle to attracting potential expatriate applicants to subsidiaries in emerging countries than to subsidiaries in developed countries.

Further, the existing work-family literature suggests that implementing family support policies can significantly affect employees' work outcome variables [18-20]. Extending this issue to the literature on expatriates, we examined the potential moderating effect of family support policies. We suggested that such effects should be more significant for a subsidiary in an emerging country, Vietnam, than for one in a developed country, the US. As expected, the results showed that the family support policies of the Vietnam-based subsidiary had a stronger positive impact on the relationship between the host country image and organizational attractiveness to Korean prospective expatriate applicants. Consequently, subsidiaries located in emerging countries, such as Vietnam, can ease the effect of having a less preferred host country image on the attractiveness of that subsidiary to potential expatriates.

\subsection{Theoretical Implications}

This study provides new insights that enrich the expatriate literature in several ways. First, it significantly contributes to this literature by particularly focusing on subsidiaries in emerging countries. Despite the rapid increase of MNEs' subsidiaries in emerging countries, few studies focus on the challenges of emerging market subsidiaries in attracting prospective expatriate candidates [4]. Thus, we investigated the differences in the attractiveness of US-based and Vietnam-based subsidiaries as expatriate destinations to Korean expatriate applicants. Our findings confirm that the host location images of US-based and Vietnam-based subsidiaries significantly differ for Korean expatriate candidates, and this difference affects the attractiveness of each subsidiary. Consequently, this study improves the understanding of the challenges, emerging market subsidiaries face, in attracting talented expatriate applicants.

Second, this study examined the effect of the host country's image and family support policies, based on the signaling theory. Signaling theory is commonly used in recruitment literature to clarify the influences of the country's image, corporate image, or corporate social responsibility (CSR) on job choice decisions of potential applicants $[9,35,49]$. Transferring this logic to the expatriate literature, this study attempts to further enrich expatriate research by explaining how signaling theory approach can 
explain the subsidiary attractiveness for potential expatriate applicants. More specifically, the country image or stereotypes of a foreign subsidiary can signal the unknown working and living conditions, by comparing it to developed (the US) and developing (Vietnam) countries. Also, family support policies can also be a cue for expatriate applicants to signal living condition of subsidiary location, thus affecting the subsidiary attractiveness. By introducing signaling theory in the expatriate recruitment process, this study enriches the understanding of potential expatriate applicants' attractions to certain nationally dispersed subsidiaries and family support programs.

Third, this study explored the positive moderating role of the family support policies of expatriate subsidiaries as a sustainable HR practice. In general, family support policies are considered a critical factor affecting employees' work outcome variables, thus leading to sustainable organization [18-20]. Extending this logic to the expatriate literature, we suggested that family support programs could be a strategy for increasing the attractiveness of subsidiaries in emerging countries, relative to those in developed countries, by overcoming issues related to a less preferred host location image. In line with our logic, we found that that the effect of family support policies was more relevant for the Vietnam-based subsidiary than for the American-based subsidiary in increasing the effect of the host country's image on organizational attractiveness. Thus, by introducing family support policies as a strategy to mitigate challenges in attracting high-quality expatriate candidates, this study significantly contributes to the expatriate literature.

\subsection{Practical Implications}

As the level of competition in international markets rapidly grows, creating and maintaining a sustainable organization may be a crucial strategic weapon over the long-term [23]. To achieve organizational sustainability, coordination between an HQ and foreign subsidiaries is more critical [5]. In the global network within an organization, expatriates play the most important role in transferring knowledge and organizational practices [2]. However, despite this crucial role of expatriates, organizations struggle to send their employees on expatriate assignments. Most expatriate candidates have emotional barriers to living and working in unfamiliar conditions. Moreover, because many expatriate candidates want their families, including their spouse and children, to accompany them on their assignments abroad, relocation to a new environment may be more challenging.

This study provides evidence that perceptions of subsidiary locations may affect the attractiveness of foreign subsidiaries to expatriate candidates differently. Expatriate candidates may be more willing to live and work in developed countries, such as the US, because they have more favorable country images. As expatriate candidates expect better social, economic, and political conditions in developed countries, they may assume that they can enjoy better working and living environments in developed countries than in developing countries. Thus, this study suggests that it is better for MNEs to provide good and valuable living conditions in expatriate locations to attract prospective expatriates to emerging market subsidiaries.

Moreover, expatriate candidates are more attracted to foreign subsidiaries that implement family support policies. Thus, it would be more helpful to adopt family support policies for expatriates to attract a large pool of potential expatriate candidates. Particularly, this study shows that the positive effect of family support policies was stronger for a subsidiary located in a less developed country than for one in a more developed country. Thus, to attract talented expatriate applicants to international assignments in emerging markets, adopting family support policies for expatriates can help to overcome the unfavorable images of such countries. As one essential signal, family support policies can serve to decrease the risks and uncertainties that expatriate candidates face in a less developed environment [22]. This study suggests that family support policies, as a sustainable HRM practice, may be an effective way for managers to overcome the unfavorable images of expatriate destinations in overseas markets.

Communicating the engagement of family support policies and providing prior communication of the family support, provided by a company, may help to attract talented expatriates to foreign subsidiaries, located in less developed countries. 
In addition, among various family support policies, support for children's well-being or education may help attract international assignments in less developed countries, especially for Korean expatriate applicants. Prior studies have found that Korean expatriates preferred to be dispatched to developed countries, compared to other countries, due to the importance placed on children's education [50]. Moreover, Kim and Tung [51] found that over one-third of married expatriates did not bring their children to India, an emerging market, because of the worries about children's education and India's cultural adaptability. Those findings show that children's educational support will be important in attracting potential Korean expatriates, especially for subsidiaries located in emerging countries. Thus, it would be advisable for Korean MNEs to seek to develop sustainable children's support programs, such as the establishment of Korean international schools in emerging countries to attract talented expatriate applicants.

\subsection{Limitations and Further Research}

This study has several limitations that suggest a need for future improvement. Although this study suggests that family support policies play a critical role in sustainable HRM practice, other effective tools can be used to attract potential expatriate candidates and, consequently, help achieve organizational sustainability in expatriate literature. This sustainability, in turn, helps to maintain knowledge sustainability between the HQ and nationally dispersed subsidiaries. Stankevičiūtè and Savanevičienè [23] suggest distinctive characteristics of sustainable HRM, such as fairness and equality, employee cooperation, compliance beyond labor regulations, flexibility, external partnerships, employee development, employee participation and social dialogue, profitability, care for the environment, care for employees, and long-term orientation. By using these sub-categories of sustainable HRM, a well-defined structural approach could be helpful for understanding different effects of HRM practices in the context of expatriate assignments. Even family support policies examined in this study are only one type of care for employees; long-term oriented practices, employee development, through the transfer experience, from the HQ to foreign subsidiaries and vice versa, and employee cooperation across subsidiaries may be important strategic tools for achieving organizational sustainability for expatriates.

Furthermore, the characteristics of the respondents require caution in generalizing the results. The respondents' ages were relatively varied and ranged from 24 to 64 years old. Focusing on the specific age group with the most concern about school-aged children and adaptation to new surroundings would make the results more generalizable. Although, Hall and Hall [52] found that having school-aged children reduces employees' willingness to expatriate, few other studies found significant effects regarding school-aged children on employees' willingness to expatriate. For further research, it would also be meaningful to observe marital status, parenting, and support for extended family members, as these factors should have substantial effects on the willingness of employees in Korea and other countries to expatriate.

To measure a host country's image, this study only included the host countries of the origin (the US or Vietnam) to examine the effect of host country image on the attractiveness of a subsidiary. However, it would be more precise and fruitful to measure the country's image using multi-items in terms of economic development, advanced science and technology, and political stability in understanding the effect of host country image in the future research.

Moreover, while this study conducted two-way ANOVA and planned contrast test by a 2 (host-locations: Vietnam versus the US) $\times 2$ (family support policies: no policy versus a good policy) between-subjects experimental design, personal characteristics and organizational perspectives could influence the consideration for expatriation assignments. Dickmann et al. [53] indicates that work/life balance issues, carrier opportunities, and length of assignment have a considerable influence on the decision of individuals to accept expatriation. Especially, individuals may assign different motives to different expatriation destinations. Depending on destination country, as a result, different consideration may influence the acceptance of expatriation assignments in a certain location. Further research would be encouraged to explore the roles of the individuals' and the job's characteristics and how they relate to the willingness to accept an expatriate assignment to different host country destinations. 
This study demonstrated the importance of family support policies for attracting expatriate candidates to foreign assignments. However, examining the effects of these independent variables on actual expatriate performance during foreign assignments will also be valuable for MNEs' long-term survival, because relocation to a foreign country involves several changes and challenges, such as establishing a new social network, adapting to a different culture, and learning a foreign language. Thus, such challenges could affect expatriate performance and could be linked to organizational performance, as expatriates play key roles in the control and coordination of subsidiaries and transferring knowledge from the HQ to subsidiaries. Thus, it would be worthwhile to explore the roles of host country image and family support policies on expatriate performance.

Finally, it would be also valuable to compare family support policies with other important factors, which may influence the attractiveness of an expatriate location, such as career development, promotion chances, and training and mentoring support from HQ [23,50]. By jointly examining various organizational support, in the relationship between host country image and the attractiveness of subsidiaries, it will be possible to provide a better understanding of the policies that are more decisive in influencing foreign assignment location choice.

Author Contributions: Conceptualization, G.H. and E.K.; methodology, E.K.; formal analysis, G.H. and E.K.; writing —original draft preparation, G.H. and E.K.; writing—-review and editing, G.H. and E.K.; project administration, E.K.; funding acquisition, G.H.

Funding: This research received no external funding.

Acknowledgments: This research was supported by the Korea University Research Grant.

Conflicts of Interest: The authors declare no conflict of interest.

\section{References}

1. Caligiuri, P.M. The big five personality characteristics as predictors of expatriate's desire to terminate the assignment and supervisor-rated performance. Pers. Psychol. 2000, 53, 67-88. [CrossRef]

2. Chang, Y.Y.; Gong, Y.; Peng, M.W. Expatriate knowledge transfer, subsidiary absorptive capacity, and subsidiary performance. Acad. Manag. J. 2012, 55, 927-948. [CrossRef]

3. Dupuis, M.J.; Haines, V.Y., III; Saba, T. Gender, family ties, and international mobility: Cultural distance matters. Int. J. Hum. Resour. Manag. 2008, 19, 274-295. [CrossRef]

4. Kim, J.; Froese, F.J. Expatriation willingness in Asia: The importance of host-country characteristics and employees' role commitments. Int. J. Hum. Resour. Manag. 2012, 23, 3414-3433. [CrossRef]

5. Bader, B.; Berg, N.; Holtbrügge, D. Expatriate performance in terrorism-endangered countries: The role of family and organizational support. Int. Bus. Rev. 2015, 24, 849-860. [CrossRef]

6. De Eccher, U.; Duarte, H. How images about emerging economies influence the willingness to accept expatriate assignments. Int. J. Hum. Resour. Manag. 2018, 29, 637-663. [CrossRef]

7. Rynes, S.L. Recruitment, job choice, and post-hire consequences: A call for new research directions. In Handbook of Industrial and Organizational Psychology, 2nd ed.; Dunnette, M.D., Hough, L.M., Eds.; Consulting Psychologists Press: Palto Alto, CA, USA, 1991; Volume 2, pp. 399-444.

8. Martin, I.M.; Eroglu, S. Measuring a multi-dimensional construct: Country image. J. Bus. Res. 1993, 28, 191-210. [CrossRef]

9. Hong, G.H.; Kim, E.M. Overcoming country-of-origin image constraints on hiring: The moderating role of CSR. Asian. Bus. Manag. 2017, 16, 253-271. [CrossRef]

10. GMT. Global Mobility Trends Survey Report. 2016. Available online: http://globalmobilitytrends.bgrs.com/ (accessed on 10 July 2019).

11. Haslberger, A.; Brewster, C. The expatriate family: An international perspective. J. Manag. Psychol. 2008, 23, 324-346. [CrossRef]

12. Tharenou, P. Disruptive decisions to leave home: Gender and family differences in expatriation choices. Organ. Behav. Hum. Decis. Process. 2008, 105, 183-200. [CrossRef]

13. Lazarova, M.; Westman, M.; Shaffer, M.A. Elucidating the positive side of the work-family interface on international assignments: A model of expatriate work and family performance. Acad. Manag. Rev. 2010, 35, 93-117. 
14. Ehnert, I. Sustainable Human Resource Management: A Conceptual and Exploratory Analysis from a Paradox Perspective; Springer: Berlin, Germany, 2009.

15. Kramar, R. Beyond strategic human resource management: Is sustainable human resource management the next approach? Int. J. Hum. Resour. Manag. 2014, 25, 1069-1089. [CrossRef]

16. Macke, J.; Genari, D. Systematic literature review on sustainable human resource management. J. Clean. Prod. 2019, 208, 806-815. [CrossRef]

17. Ehnert, I. Sustainability Issues in Human Resource Management: Linkages, theoretical approaches, and outlines for an emerging field. In Proceedings of the 21st EIASM Workshop on SHRM, Aston, UK, 30-31 March 2006.

18. Allen, T.D. Family-supportive work environments: The role of organizational perceptions. J. Vocat. Behav. 2001, 58, 414-435. [CrossRef]

19. Cook, A. Connecting work-Family policies to supportive work environments. Group Organ. Manag. 2009, 34, 206-240. [CrossRef]

20. Wayne, J.H.; Casper, W.J.; Matthews, R.A.; Allen, T.D. Family-supportive organization perceptions and organizational commitment: The mediating role of work-Family conflict and enrichment and partner attitudes. J. Appl. Psychol. 2013, 98, 606-662. [CrossRef]

21. World Investment Report 2017. Available online: https://unctad.org/en/PublicationsLibrary/wir2017_en.pdf (accessed on 19 September 2019).

22. Cho, T.; Hutchings, K.; Marchant, T. Key factors influencing Korean expatriates' and spouses' perceptions of expatriation and repatriation. Int. J. Hum. Resour. Manag. 2013, 24, 1051-1075. [CrossRef]

23. Stankevičiūtè, Ž.; Savanevičienè, A. Designing sustainable HRM: The core characteristics of emerging field. Sustainability 2018, 10, 4798. [CrossRef]

24. De Prins, P.; Van Beirendonck, L.; De Vos, A.; Segers, J. Sustainable HRM: Bridging theory and practice through the 'Respect Openness Continuity (ROC)'-model. Manag. Rev. 2014, 25, 263-284. [CrossRef]

25. Wehling, C.; Hernandez, A.G.; Osland, J.; Osland, A.; Deller, J.; Tanure, B.; Neto, A.C.; Sairaj, A. An exploratory study of the role of HRM and the transfer of German MNC sustainability values to Brazil. Eur. J. Int. Manag. 2009, 3, 176-198. [CrossRef]

26. Kogut, B.; Zander, U. Knowledge of the firm and the evolutionary theory of the multinational corporation. J. Int. Bus. Stud. 1993, 24, 625-645. [CrossRef]

27. Tan, D.; Mahoney, J.T. Why a multinational chooses expatriates: Integrating resource-agency, and transaction costs perspectives. J. Manag. Stud. 2006, 43, 457-484. [CrossRef]

28. Turban, D.B.; Keon, T.L. Organizational attractiveness: An interactionist perspective. J. Appl. Psychol. 1993, 78, 184-193. [CrossRef]

29. Lievens, F.; Van Hoye, G.; Schreurs, B. Examining the relationship between employer knowledge dimensions and organizational attractiveness: An application in a military context. J. Occup. Organ. Psychol. 2005, 78, 553-573. [CrossRef]

30. Turban, D.B.; Forret, M.; Hendrickson, C. Applicant attraction to firms: Influences of organization reputation, job and organizational attributes, and recruiter behavior. J. Vocat. Behav. 1998, 52, 24-44. [CrossRef]

31. Van Hoye, G.; Saks, A.M. The instrumental-symbolic framework: Organizational image and attractiveness of potential applicants and their companions at a job fair. Appl. Psychol. 2011, 60, 311-335. [CrossRef]

32. Peltokorpi, V.; Froese, F. Organizational expatriates and self-initiated expatriates: Who adjusts better to work and life in Japan? Int. J. Hum. Resour. Manag. 2009, 20, 1096-1112. [CrossRef]

33. Allred, A.; Chakraborty, G.; Miller, S.J. Measuring images of developing countries: A scale development study. J. Euromark. 2000, 8, 29-49. [CrossRef]

34. Newburry, W.; Gardberg, N.A.; Belkin, L.Y. Organizational attractiveness is in the eye of the beholder: The interaction of demographic characteristics with foreignness. J. Int. Bus. Stud. 2006, 37, 666-686. [CrossRef]

35. Froese, F.; Garrett, T. Organizational attractiveness of foreign-based companies: A country of origin perspective. Int. J. Sel. Assess. 2010, 18, 271-289. [CrossRef]

36. Spence, M. Job market signaling. Q. J. Econ. 1973, 87, 355-374. [CrossRef]

37. Turban, D.B.; Cable, D.M. Firm reputation and applicant pool characteristics. J. Organ. Behav. 2003, 24, 733-751. [CrossRef]

38. Ehrhart, K.H.; Ziegert, J.C. Why are individuals attracted to organizations? J. Manag. 2005, 31, 901-919. [CrossRef] 
39. Highhouse, S.; Thornbury, E.E.; Little, I.S. Social-identity functions of attraction to organizations. Organ. Behav. Hum. Decis. Process. 2007, 103, 134-146. [CrossRef]

40. Galinsky, E.; Aumann, K.; Bond, J.T. Times are changing: Gender and generation at work and at home in the USA. In Expanding the Boundaries of Work-Family Research; Palgrave Macmillan: London, UK, 2013; Volume 13, pp. 279-296.

41. Matos, K.; Galinsky, S. National Study of Employers, the Families and Work-Institute. 2014. Available online: http://familiesandwork.org/site/research/reports/2014nse.pdf (accessed on 7 July 2019).

42. Friedman, D.E. Work and family: The new strategic plan. Hum. Resour. Plann. 1992, 13, 297-307.

43. Bourdieu, P. On the family as a realized category. Theory Cult. Soc. 1996, 13, 19-26. [CrossRef]

44. Ezra, M.; Deckman, M. Balancing work and family responsibilities: Flexible and childcare in the federal government. Public Adm. Rev. 1996, 56, 174-179. [CrossRef]

45. Richardson, J.; McKenna, S. Exploring relationships with home and host countries: A study of self-directed expatriates. Cross Cult. Manag. 2006, 13, 6-22. [CrossRef]

46. Takeuchi, R.; Yun, S.; Russell, J.E. Antecedents and consequences of the perceived adjustment of Japanese expatriates in the USA. Int. J. Hum. Resour. Manag. 2002, 13, 1224-1244. [CrossRef]

47. Harrison, D.A.; Shaffer, M.A.; Bhaskar-Shrinivas, P. Going places: Roads more and less traveled in research on expatriate experiences. In Research in Personnel and Human Resources Management; Emerald Group Publishing Limited: Bingley, UK, 2004; Volume 23, pp. 154-196.

48. Turban, D.B. Organizational attractiveness as an employer on college campuses: An examination of the applicant population. J. Vocat. Behav. 2001, 58, 293-312. [CrossRef]

49. Greening, D.W.; Turban, D.B. Corporate social performance as a competitive advantage in attracting a quality workforce. Bus. Soc. 2000, 39, 254-280. [CrossRef]

50. Kim, K.; Slocum, J.W., Jr. Individual differences and expatriate assignment effectiveness: The case of US-based Korean expatriates. J. World Bus. 2008, 43, 109-126. [CrossRef]

51. Kim, H.D.; Tung, R.L. Opportunities and challenges for expatriates in emerging markets: An exploratory study of Korean expatriates in India. Int. J. Hum. Resour. Manag. 2013, 24, 1029-1050. [CrossRef]

52. Hall, F.S.; Hall, D.T. Dual career: How do couples and companies cope with the problems? Organ. Dyn. 1978, 6, 57-77. [CrossRef]

53. Dickmann, M.; Doherty, N.; Mills, T.; Brewster, C. Why do they go? Individual and corporate perspectives on the factors influencing on the decision to accept an international assignment. Int. J. Hum. Resour. Manag. 2008, 19, 731-751. [CrossRef]

(C) 2019 by the authors. Licensee MDPI, Basel, Switzerland. This article is an open access article distributed under the terms and conditions of the Creative Commons Attribution (CC BY) license (http://creativecommons.org/licenses/by/4.0/). 